\title{
Fallgruver for helsetjenesten
}

\author{
Dagens helsevesen, med gjennomgående høy kvalitet, relativt lave egenandeler og gratis sykehusinn- \\ leggelser, er ikke kommet av seg selv. Ingen naturlov tilsier at utviklingen ville bli slik. Byggverket er reist \\ på to pilarer: humanisme og naturvitenskap. Men hvor går veien videre?
}

Steinar Krokstad

steinar.krokstad@ntnu.no

Mot alle «naturlover» eller, mer presist, mot «loven om den omvendte omsorg» (1) har vi i Norge greid å utvikle en offentlig, solidarisk og rettferdig helsetjeneste for hele befolkningen (2). I tidligere tider var helsetjenestene som regel forbeholdt dem som hadde råd til å betale for seg. Rundt omkring i verden er dette fortsatt ofte en realitet. Selv i USA, et av verdens rikeste land, er kampen for en anstendig og solidarisk helsetjeneste fortsatt ikke vunnet (3).

Kvaliteten i pasientbehandlingen her til lands er også gjennomgående høy, noe blant annet kreftoverlevelsesstatistikken viser (4). Medisinens naturvitenskapelige fundament har bidratt til kontinuerlig forbedring gjennom forskning, selvkritiske analyser, utvikling av nye hypoteser og etterprøving av resultater.

Men helsetjenestene våre står overfor utfordringer og trusler. Noen av dem gjelder hvilken styringsideologi som bør ligge til grunn (5). Det er flere fallgruver som må unngås hvis vi skal greie å ivareta og videreutvikle de sentrale verdiene i dagens tjenester. Vi må unngå urettferdig fordeling, utvanning av verdigrunnlaget, dalende tillit, feilprioritering, overforbruk og manglende pasientsentrert medvirkning.

\section{Urettferdig fordeling}

De offentlige helsetjenestene vi har utviklet i Norge blir av mange betraktet som den mest siviliserte og moderne måten å organisere slike tjenester på (6). Historikere er stort sett enig om at en viktig drivkraft for utviklingen av statlig velferd har vært en tydelig arbeiderbevegelse som greide å få reell makt og sette dagsorden med visjoner om et mer rettferdig samfunn (7). Det er lett å ta dagens organisering for gitt. Velferdsmodellen har internasjonalt ry for å være den beste, men mange utviklingstrekk bærer bud om at den kan være i fare.

I England har man også hatt gode felles skattefinansierte helsetjenester (National Health Service) (8). Men nå er det krise. Helsetjenesten er i ferd med å brytes ned, til tross for bred motstand fra fagfolk (9). Det som skjer i England er et viktig eksempel på at selv velrenommerte offentlige helsesystemer kan møte markedets makt og privatiseringens fristelser (10).

Den eneste garantien for en anstendig helsetjeneste for alle er at alle får det samme tilbudet (11). I Norge er det i dag et betydelig press for å etablere flere private tjenester, med relaterte private helseforsikringer. Ettersom helsetjenester alltid er og alltid vil være et knapphetsgode (12), vil private helsetjenester tappe det offentlige for ressurser gjennom flere mekanismer. Det offentlige tappes for helsepersonellressurser, finansiering fra Nav, de friskeste pasientene med best prognose, utdanningsressurser (færre skal utdanne flere) og tillit $i$ befolkningen. Tilliten til det offentlige reduseres fordi det er mye lettere å organisere og drive private helsetjenester når man selekterer de friskeste pasientene og samtidig bruker ressurser på reklame.

Fellesskapsløsningene må være så gode at flertallet ser seg tjent med dem. I det øyeblikket flertallet føler behov for å se seg om etter private ordninger, reduseres viljen til å betale skatt - og ordningene faller sammen (13). Vi ender raskt opp med et urettferdig todelt helsevesen.

\section{Verdiutvanning og dalende tillit}

Markedsløsninger fungerer på mange måter bra innen varehandel og industri. På grunn av utilstrekkelig regulering blir riktignok sosiale, økonomiske og helsemessige forskjeller ofte ubehagelig store (14). Mange har en idé om at markedsløsninger også vil virke positivt $i$ helsetjenestene. Noe av denne tenkningen lå til grunn for sykehusreformen i 2002 (15) og ligger til grunn for reformene i England nå (10).

Det er flere årsaker til at markedsmekanismer fungerer dårlig i helsevesenet. Én av dem er at markedets og helsetjenestenes spilleregler og verdigrunnlag er helt forskjellige. Hvis en helsetjeneste endres fra å være en handling som bunner i ønsket om å hjelpe noen til å bli en handling begrunnet $\mathrm{i}$ ønsket om å tjene mer penger, forvitrer verdigrunnlaget $(2,11)$. Det vil skje en glidning fra en arena hvor man kan forvente empati og omsorg til en arena der leger i økende grad blir selgere som konkurrerer om «kundene». Tilliten forvitrer fordi pasienten ikke føler seg trygg på hva som er motivet bak tjenestetilbudet. Relasjonen mellom lege og pasient forringes. Behandlingseffekten svekkes, fordi placebo byttes ut med nocebo. Omkostningene $ø$ ker, fordi alt dette fører til økende tilbud, økende etterspørsel og økende behov for kontroll fra offentlige myndigheter $(12,16,17)$.

\section{Feilprioritering og overforbruk}

John E. Wennbergs analyser av regionale forskjeller i bruk av helsetjenester holdt opp mot objektive mål for helse viser hvor det er rom for kostnadsreduksjoner og prioriteringer i helsetjenestene (17). Wennberg kategoriserer helsetjenester i tre grupper.

Den første kategorien kalles effektive og nødvendige helsetjenester. Dette er helsetjenester ingen stiller spørsmål ved nytten av, verken i medisinske fagkretser, blant politikerne eller i befolkningen. Eksempler på denne typen tjenester kan være akuttmedisin ved traumer, antibiotikabehandling av alvorlige infeksjoner og vaksineringsprogrammer. Hovedutfordringen med denne typen behandling er å unngå urettferdig sosial og geografisk fordeling av tilbudet $(18,19)$. I den offentlige debatt om helsetjenestene synes det å være en utbredt misforståelse at all medisinsk behandling er nødvendige helsetjenester. I virkeligheten utgjør denne kategorien kanskje bare en femdel av alle helsetjenester i Norge, en antakelse jeg baserer på Wennbergs studier i USA, som viste at denne kategorien bare utgjorde $15 \%$ av det totale helsetjenesteforbruket (17).

Den andre kategorien kaller Wennberg valgsensitive helsetjenester. Dette er helsetjenester der det finnes to eller flere reelle valg for hvilke tiltak som kan iverksettes (17). Eksempler kan være innsetting av proteser ved slitasjegikt, behandling av mild hypertensjon, kontroll hos spesialist, mange utredende undersøkelser og screeningprogrammer. Hovedutfordringen med denne typen tjenester er at bruken i for stor grad avhenger av legenes egne erfaringer, i varierende grad av medisinsk kunnskapsgrunnlag og i for liten grad av pasientens preferanser (17). 


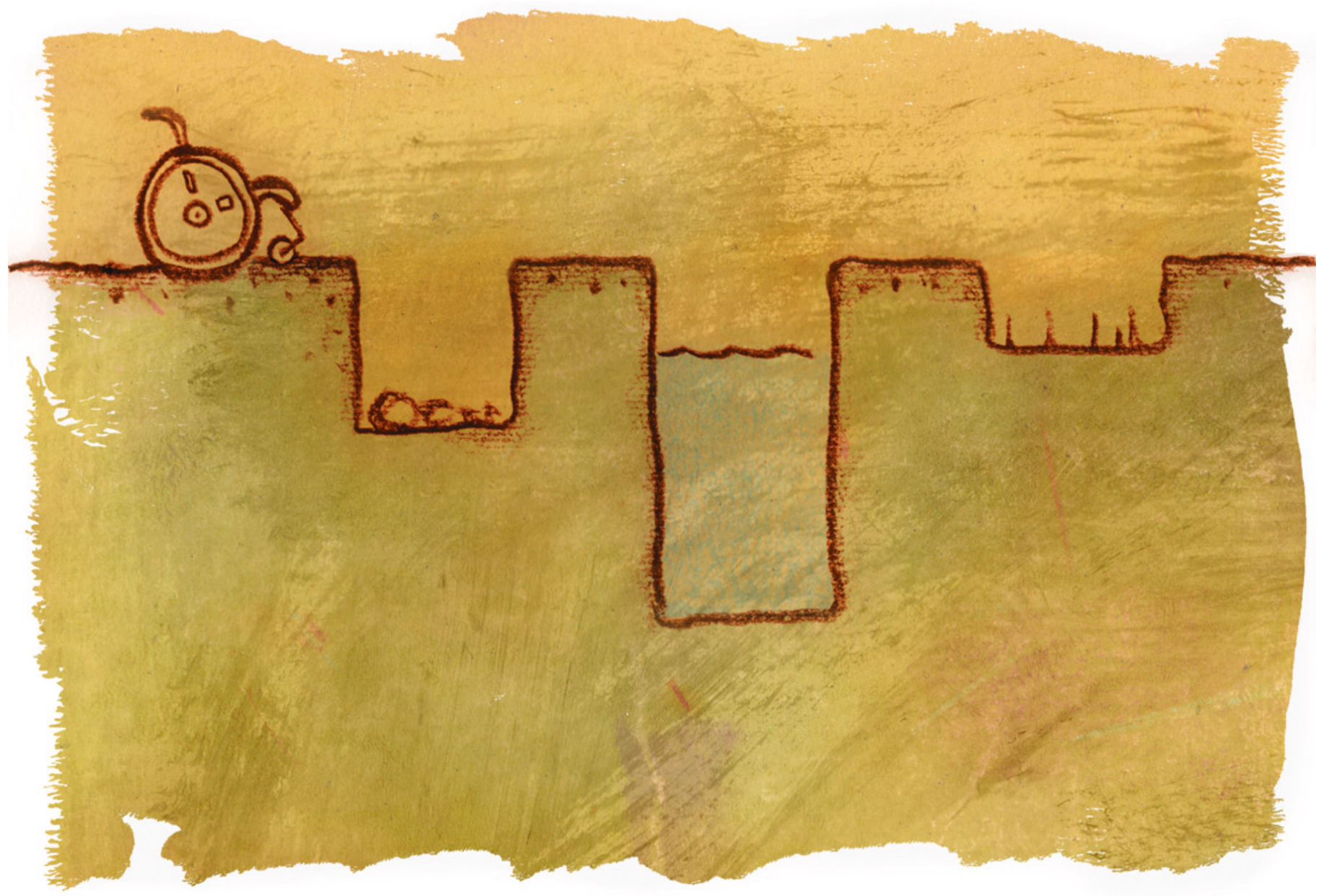

Illustrasjon (c) Stein Løken

Problemene er knyttet til store variasjoner i praksis og manglende evaluering av behandlingsresultater (20). Pasientene er i for liten grad med på de reelle valg, selv om det er utviklet metoder for pasientmedvirkning (17). Dersom pasienter kan velge på informert grunnlag, tyder undersøkelser på at mange sier nei takk til kostbare behandlinger og ja til enklere løsninger (17). Her ligger det sannsynligvis et potensial for kostnadsreduksjon i helsetjenestene i Norge (20). Wennberg viste at denne kategorien utgjorde $25 \%$ av det totale helsetjenesteforbruket i USA (17).

Den tredje kategorien kaller Wennberg tilbudssensitive helsetjenester. Den omhandler ikke spesifiserte behandlinger eller tjenester, som over, men beskriver tjenester som varierer i omfang på grunn av variasjoner i hva som er tilgjengelig. Eksempler på slike tjenester er mange spesialistkonsultasjoner (21), sykehusinnleggelser (22), behandling hos fysioterapeut, kiropraktor og i alternativbransjen. Hovedutfordringen for slike helsetjenester er at omfanget varierer i betydelig grad etter hva som tilbys, uten at det fører til påviselig bedre helse eller lavere dødelighet $\mathrm{i}$ befolkningen (17). Det fører ofte til høyere kostnader, flere unødvendige bivirkninger $(20,23)$, uryddigere helsetjenester og lavere pasienttilfredshet (17).

Vi trenger mer kunnskap om hva som er et fornuftig omfang av helsetjenestetilbud og en langt større bevissthet hos fagfolk og helsepolitikere omkring forholdet mellom tilbud og etterspørsel. Det vi ikke trenger, er et økende omfang av helsetilbud i et åpent helsemarked. Det vil gi økte omkostninger og flere behandlingsrelaterte skader (20). Tilbudssensitive helsetjenester utgjør kanskje over halvparten av helsetjenestene i Norge. Her ligger det trolig et potensial for kostnadsreduksjon og dermed armslag for omprioriteringer.

Utfordringen med feilprioriteringer og overforbruk i helsetjenesten handler med andre ord om å prioritere og fordele effektive og nødvendige helsetjenester rettferdig, heve kvaliteten på og redusere omfanget av valgsensitive tjenester og regulere tilbudssensitive helsetjenester til et dokumentert fornuftig nivå. Dette er en stor utfordring for den medisinske profesjon. Hvis vi ikke tar den selv, vil andre forsøke med mer uvitenskapelige metoder (5).

\section{Empati og pasientmedvirkning}

Helsepersonellets viktigste ferdighet, evnen til empati og til å ivareta pasientens behov, må beskyttes og dyrkes. Empatien kan være truet av flere forhold: økonomi, teknologi, narsissisme og mangelfull utdanning. Den forste trusselen henger sammen med utvikling av markedsløsninger i helsetjenestene og utvanning av kjerneverdiene.

Det er krevende stadig å møte mennesker som har alvorlige helseplager eller som er redde for at de har fått en alvorlig eller dødelig sykdom. Hvis legene ikke har utviklet gode holdninger eller ferdigheter til å takle denne utfordringen, er det mange psykologiske mekanismer som kan tre $\mathrm{i}$ kraft for å unnvike de viktigste oppgavene. I dagens helsetjeneste er bruk av teknologi, det å bestille flere avanserte undersøkelser, en slik mekanisme.

Narsissisme er et begrep for atferd knyttet 
til individets oppfatning av seg selv i relasjon til omgivelsene. Makt- og kunnskapsforskjeller mellom lege og pasient kan utløse tanker hos legene om at de selv er best i stand til å ta valg for pasienten. Man kan tilby behandling uten å ta pasientene med på råd. Mange pasienter føler seg forpliktet til å ta imot det som tilbys, selv om de kanskje selv ville valgt en enklere løsning. Et paradoks som understreker dette forholdet er at leger ofte velger enklere løsninger for seg selv enn det de tilbyr av behandling til sine pasienter (24).

En fjerde årsak til mangel på empati blant helsepersonell kan være at temaet ikke vektlegges nok i rekruttering, utdanning og veiledning. Flere trekk ved det moderne helsevesenet kan altså true helsepersonellets evne til empati.

\section{Kunnskapsgrunnlag}

Det finnes god dokumentasjon for å videreføre hovedtrekkene i det norske helsevesenet: Et felles, solidarisk, skattefinansiert helsevesen bygd på humanisme og naturvitenskap. Å unngå fallgruvene blir en viktig oppgave for alle med ansvar for helsetjenestene.

\section{Steinar Krokstad (f. 1958)}

er førsteamanuensis i sosialepidemiologi ved HUNT forskningssenter, Institutt for samfunnsmedisin, Norges teknisk-naturvitenskapelige universitet, og overlege i psykiatri ved Sykehuset Levanger.

Forfatter har fylt ut ICMJE-skjemaet og oppgir ingen interessekonflikter.

\section{Litteratur}

1. Hart JT. The inverse care law. Lancet $1971 ; 1$ 405- 12.

2. Lian OS. Når helse blir en vare: medikalisering og markedsorientering i helsetjenesten. Kristiansand: Høyskoleforlaget, 2003.

3. Obama and health: change can happen. Lancet 2008; $372: 1707$

4. OECD. HCQI cancer care. www.oecd.org/health/ health-systems/hcqicancercare.htm (30.5.2013).

5. Wyller VB, Gisvold SE, Hagen E et al. Ta faget tilbake! Tidsskr Nor Legeforen 2013; 133: 655-9.

6. Tudor Hart J. Commentary: three decades of the inverse care law. BMJ 2000; 320: 18-9.

7. Westin S. Velferd.og helse i folketrygdens århundre. Tidsskr Nor Lægeforen 1999; 119: 4507-13.

8. Westin S. The NHS's 50 anniversary. As others see us: views from abroad. A great leap for humankind? BMJ 1998; 317: 49-51.

9. The end of our National Health Service. Lancet 2011; 377: 353.

10. Leys C, Player S. The plot against the NHS. London: Merlin Press, 2011.

11. Hart JT. The political economy of health care. A clinical perspective. Bristol: The Policy Press, University of Bristol, 2006.

12. Maslow AH. Motivation and personality. New York: Harper \& Brothers, 1954

13. Esping-Andersen G. The three worlds of welfare capitalism. Cambridge: Polity Press, 1990

14. Kvåle G, Heggenhougen K. Økende forskjeller dårligere folkehelse. Tidsskr Nor Lægeforen 2006 126: $1950-1$.

15. Pettersen IJ. Fra plan til marked - noen perspektiver på sykehusreformen. Tidsskr Nor Lægeforen 2001; 121: 2186-8.
16. Lian OS. Behovet for helsetjenester - naturgitt eller sosialt bestemt? Tidsskr Nor Lægeforen 2000; 120: $111-4$

17. Wennberg JE. Tracking medicine. A researcher's quest to understand health care. Oxford: Oxford University Press, 2010.

18. Vikum E, Krokstad S, Holst D et al. Socioeconomic inequalities in dental services utilisation in a Norwegian county: the third Nord-Trondelag Health Survey. Scand J Public Health 2012; 40: 648-55.

19. Kelsall HL, Baglietto L, Muller D et al. The effect of socioeconomic status on survival from colorectal cancer in the Melbourne Collaborative Cohort Study. Soc Sci Med 2009; 68: 290-7.

20. Moynihan R, Smith R. Too much medicine? BM 2002: 324: 859-60.

21. Deraas TS, Berntsen GR, Hasvold T et al. Is a high level of general practitioner consultations associated with low outpatients specialist clinic use? A cross-sectional study. BMJ Open 2013; 3: e002041.

22. Hotvedt R. Thoner J, Wilskow AW et al. How urgent are emergency admissions? An evaluation of emergency admissions to general hospitals in a Norwegian county. Int J Technol Assess Health Care 1999; 15: 699-708.

23. Hotvedt R, Førde OH. Doctors are to blame for perceived medical adverse events. A cross sectional population study. The Troms $\varnothing$ Study. BMC Health Serv Res 2013; 13: 46

24. Murray K. How doctors die. It's not like the rest of us, but it should be. Zócalo Public Square 11.3.2011. www.zocalopublicsquare.org/2011/11/ 30/how-doctors-die/ideas/nexus/ (30.5.2013).

Mottatt 30.4. 2013, første revisjon innsendt 13.5. 2013, godkjent 21.5. 2013. Medisinsk redaktør Hanne Støre Valeur.

Engelsk oversettelse på www.tidsskriftet.no

Publisert først på nett 